\title{
Effects of Corticosteroids on Osteopontin Expression in a Murine Model of Allergic Asthma
}

\author{
Masatsugu Kurokawa $^{a, c}$ Satoshi Konnob,c Satoshi Matsukura ${ }^{a}$ \\ Mio Kawaguchi ${ }^{a}$ Koushi leki ${ }^{a}$ Shintarou Suzuki ${ }^{a}$ Miho Odaka ${ }^{a}$ \\ Shin Watanabe ${ }^{a}$ Tetsuya Homma $^{a}$ Masayuki Sato ${ }^{a}$ Hiroko Takeuchia \\ Takashi Hirose $^{\mathrm{a}}$ Shau-Ku Huang ${ }^{c}$ Mitsuru Adachi ${ }^{\mathrm{a}}$ \\ ${ }^{a}$ Division of Respiratory Medicine and Allergology, Department of Internal Medicine, Showa University School of \\ Medicine, Tokyo, and ${ }^{b}$ First Department of Internal Medicine, Hokkaido University School of Medicine, Hokkaido, \\ Japan; 'Johns Hopkins University, Asthma and Allergy Center, Baltimore, Md., USA
}

\section{Key Words}

Osteopontin • Corticosteroid • Mouse $\cdot$ Dendritic cells •

CD11c $\cdot$ Bronchial asthma

\begin{abstract}
Background: Osteopontin (OPN) contributes to the development of T helper 1 (Th1)-mediated immunity and Th1-associated diseases. However, the role of OPN in bronchial asthma is unclear. Corticosteroids reduce airway inflammation, as reflected by the low eosinophil and T-cell counts, and the low level of cytokine expression. We investigated OPN production and the inhibitory effects of corticosteroids on OPN production in a murine model of allergic asthma. Methods: $B A L B / C$ mice were sensitized by intraperitoneal injections of ovalbumin (OVA) with alum. Some mice received daily injections of dexamethasone (DEX) or phosphate-buffered saline for 1 week. All OVA-challenged mice were exposed to aerosolized 1\% OVA for $30 \mathrm{~min}$ an hour after these injections. After the OVA challenge, the mice were killed, and bronchoalveolar lavage (BAL) fluid and lung tissue were examined. Results: The levels of OPN protein in BAL fluid
\end{abstract}

\section{KARGER}

๑ 2009 S. Karger AG, Basel

Fax +4161306 1234

E-Mail karger@karger.ch

www.karger.com
Accessible online at: www.karger.com/iaa and OPN mRNA in lung tissue increased after OVA challenge. Most OPN-expressing cells were CD11c+ cells and some were $T$ cells. DEX decreased the levels of OPN protein in the BAL fluid, and those of OPN mRNA and OPN protein in lung tissue. Conclusions: OPN may play an important role in allergic bronchial asthma. Corticosteroids inhibit OPN production in mice with allergic asthma. The beneficial effect of corticosteroids in bronchial asthma is partly due to their inhibitory effects on OPN production.

Copyright $\odot 2009$ S. Karger AG, Basel

\section{Introduction}

Osteopontin (OPN, also known as SPP) is a secreted phosphorylated acidic glycoprotein that performs numerous functions. It contains the amino acid domains RGD and SVVRGLR (SLAYGLR in mouse OPN) [1, 2], which bind various types of integrins, and it facilitates the adhesion and migration of several inflammatory cells [3-7]. Many studies have demonstrated that OPN contributes to the development of T helper (Th1)-mediated 
immunity and Th1-associated diseases $[8,9]$. Increased levels of OPN expression have been observed in several Th1-associated diseases, including rheumatoid arthritis $[10,11]$, sarcoidosis $[12,13]$, tuberculosis $[14,15]$, and multiple sclerosis $[16,17]$.

Asthma is an inflammatory disease characterized by chronic infiltration of the airway by several types of inflammatory cells, including lymphocytes, eosinophils, and dendritic cells (DCs) $[18,19]$. T lymphocytes have been suggested to play a role in the pathogenesis of bronchial asthma. Th2 cells produce cytokines such as interleukin (IL)-4, IL-5, and IL-13, that induce immunoglobulin (Ig) E production and eosinophil activation. The number of Th2 cells in the airway increases in allergic asthma and further increases after allergen challenge [20, 21]. DCs are crucial for determining the functional outcome after exposure of lung tissue to allergens. Antigen presentation by myeloid DCs leads to the sensitization of Th2 cells, which is a typical characteristic of allergic diseases [22].

However, the role of OPN in Th2-associated allergic asthma has not yet been elucidated thus far. In the present study, we examined the effects of corticosteroids on OPN production in a murine model of allergic asthma.

\section{Animals and Methods}

\section{Animals}

Five-week-old BALB/c male mice were purchased from Sankyo Co. Inc. (Tokyo, Japan). All experiments were performed in accordance with the guidelines for animal experimentation issued by Showa University (Tokyo, Japan).

\section{Antigen Sensitization and Challenges}

The protocol for antigen sensitization and challenge has been previously described [23, 24]. Mice were actively sensitized by intraperitoneal injection of $50 \mu$ g ovalbumin (OVA) (grade V; Sigma, Tokyo, Japan) with $1 \mathrm{mg}$ alum (Sigma) on days $0,7,14$, and 21 of the experiment. Mice were exposed to aerosolized 1\% OVA (MIPS Co. Inc., Osaka, Japan) for $30 \mathrm{~min}$ on days 28-35 for antigen sensitization. On day 38 , the mice were challenged with aerosolized 1\% OVA. Following this, they were then killed, and $24 \mathrm{~h}$ after the challenge, bronchoalveolar lavage (BAL) fluid and lung tissue samples were obtained. Control mice were sensitized and challenged with phosphate-buffered saline (PBS).

\section{Study Design}

Mice were divided into three groups: (1) PBS-sensitized, PBSchallenged, and PBS-treated mice (control group); (2) OVA-sensitized, OVA-challenged, and PBS-treated (OVA group), and (3) OVA-sensitized, OVA-challenged, and dexamethasone (DEX)treated mice (DEX group).

\section{DEX Injection}

The mice were administered an intraperitoneal injection of $3 \mathrm{mg} / \mathrm{kg}$ of water-soluble DEX (Sigma) in PBS $1 \mathrm{~h}$ before OVA administration on days $28-35$ and on day 38 . The control mice received injections of $0.2 \mathrm{ml}$ of PBS.

\section{$B A L$}

To perform BAL, the trachea was cannulated under anesthesia, and PBS $(0.6 \mathrm{ml})$ at room temperature was injected three times into the lung via the trachea. The BAL fluid was withdrawn and stored on ice. The cells in the BAL fluid were counted, and a cytospin sample (Shandon Scientific, Runcorn, UK) was prepared. Cells were stained with Diff-Quick (Kokusai Shinyaku Co., Kobe, Japan), and a differential count of 200 cells was performed using standard morphologic criteria. The remaining BAL fluid was centrifuged at $300 \mathrm{~g}$ for $10 \mathrm{~min}$, and the supernatant was collected and stored at $-80^{\circ} \mathrm{C}$ until OPN measurement. The level of OPN in the BAL fluid was measured using a mouse OPN enzyme immunometric assay kit (Assay Designs, Ann Arbor, Mich., USA) according to the manufacturer's instructions.

\section{Real-Time Polymerase Chain Reaction}

Total RNA was isolated from lung specimens using Isogen reagent (Nippon Gene Co. Ltd, Tokyo, Japan). First-strand cDNA was synthesized using a cDNA-extraction kit (Amersham Biosciences, Little Chalfont, UK). OPN expression was evaluated by real-time quantitative polymerase chain reaction (PCR), which was performed using the ABI PRISM 7900HT Sequence Detection System (Applied Biosystems, Foster City, Calif., USA). An oligonucleotide probe was designed to anneal to the target gene between the two PCR primers. The probe was fluorescently labeled with 6-carboxyfluorescein (reporter gene) on the $5^{\prime}$ end and with 6-carboxytetramethylrhodamine (quencher dye) on the $3^{\prime}$ end. A similar probe and PCR primers were purchased for $18 \mathrm{~S}$ ribosomal RNA (Applied Biosystems). This second probe incorporated $\mathrm{VIC}^{\mathrm{TM}}$ as the reporter dye (Applied Biosystems). In the case of both genes, PCR was performed using the primers and probes as well as cDNA prepared from the cells. As the polymerase moved across the gene during the reaction, it cleaved the dye from one end of each probe. This resulted in the emission of fluorescence, which was measured using the Sequence Detection System. Emissions were recorded for each cDNA and can then be converted to determine the gene expression level after normalization to the expression of $18 \mathrm{~S}$ ribosomal RNA.

Data analysis was performed using the 7900HT Sequence Detection System software (version 2.1; Applied Biosystems). Data from real-time PCR were plotted as the $\Delta \mathrm{Rn}$ fluorescence signals versus the cycle number. $\Delta \mathrm{Rn}$ was calculated using the following equation: $\Delta R n=(R n+)-(R n-)$, where $R n+$ is the fluorescence signal of production and $\mathrm{Rn}$ - is the fluorescence signal of the baseline emission. Ct was defined as the cycle number at which the $\Delta \mathrm{Rn}$ crossed threshold. Fold changes in OPN cDNA were determined as follows: fold change $=2^{\Delta \mathrm{Ct}}[23,25]$.

\section{Immunohistochemical Examination}

Lung tissue specimens were fixed in $4 \%$ neutral buffered formalin and embedded in paraffin. The paraffin-embedded specimens were sectioned, and the sections were deparaffinized for 20 min in xylene, dehydrated for 5 min each in 100, 95, 90, and 70\% ethanol, and then washed with PBS for $10 \mathrm{~min}$. 


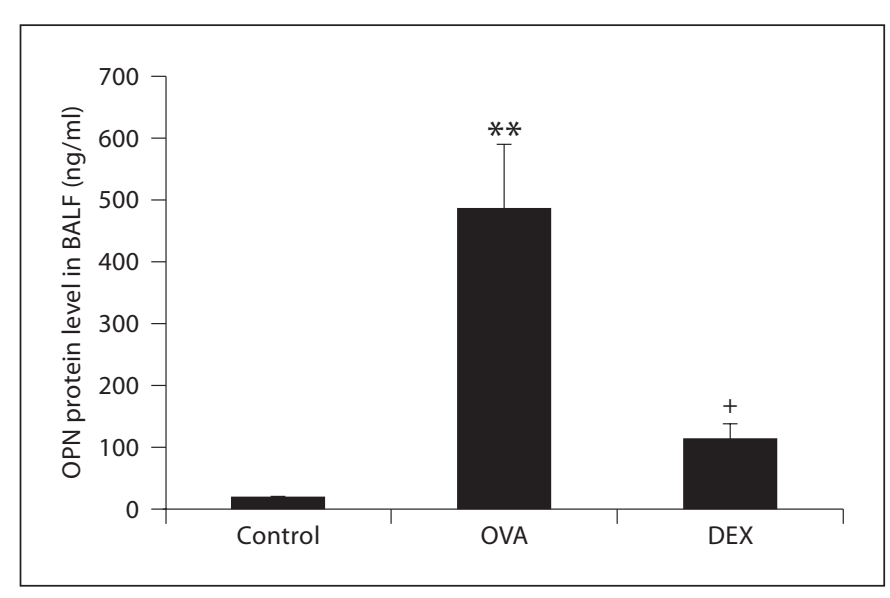

Fig. 1. OPN protein in BAL fluid and the effect of DEX on the OPN protein. The OPN protein levels in BAL fluid were significantly higher at $24 \mathrm{~h}$ after antigen challenge in the OVA-challenged mice than in the control mice. DEX significantly decreased the OPN protein levels in BAL fluid at $24 \mathrm{~h}$ after OVA challenge. ** OVA compared with control $(\mathrm{p}<0.01) .{ }^{+}$DEX compared with OVA $(\mathrm{p}<0.05)$.

After the slides were deparaffinized, they were immersed in $10 \mathrm{mM}$ citric acid buffer ( $\mathrm{pH}$ 6.0) and heated in an autoclave at $121^{\circ} \mathrm{C}$ for $10 \mathrm{~min}$. Endogenous peroxidase activity was blocked by incubation in $0.3 \%$ hydrogen peroxide in methanol for $30 \mathrm{~min}$.

\section{OPN Staining}

Tissue sections were incubated overnight with goat anti-mouse polyclonal OPN antibody (dilution, 1:100; Santa Cruz Biotechnology, Santa Cruz, Calif., USA) at $4^{\circ} \mathrm{C}$ overnight. Secondary antibodies were detected by incubation with Histofine Simple Stain mouse MAX-Po (goat) reagent (Nichirei Co., Tokyo, Japan) for 30 min at room temperature. Peroxidase activity was detected with 3-amino-9-ethyl carbazole solution (Nichirei). Sections were counterstained with Mayer's hematoxylin.

\section{Immunofluorescence Staining for OPN, CD11c, and CD4}

Lung tissue specimens were submerged in $4 \%$ formaldehyde in PBS at $4{ }^{\circ} \mathrm{C}$ for $2 \mathrm{~h}$. They were incubated overnight with $18 \%$ sucrose in PBS. They were then blotted dry and embedded in optimal cutting temperature compound, and frozen at $-80^{\circ} \mathrm{C}$. Frozen tissues were cut sectioned and mounted on slides. The slides were covered with goat blocking solution, $10 \%$ goat serum, $1 \%$ bovine serum album (BSA), 0.5\% Tween 20 in PBS, for $1 \mathrm{~h}$ at room temperature. They were then covered with rabbit anti-mouse OPN antibody (Assay Designs) diluted in Triton/BSA PBS (PBS containing $0.3 \%$ Triton X-100, 1\% BSA). They were also covered with one of the following two antibodies: mouse anti-mouse CD11c antibody (Miltenyi Biotec, Auburn, Calif., USA) or mouse antimouse CD4 antibody (BD Bioscience Pharmingen, San Diego, Calif., USA) diluted overnight in Triton/BSA PBS at $4^{\circ} \mathrm{C}$. The slides were covered with fluorescent-labeled anti-primary antibody (goat anti-mouse IgG Alexa 488, and goat anti-rabbit IgG Alexa 594) (Molecular Probes, Eugene, Oreg., USA) diluted in

Effect of Corticosteroids on OPN

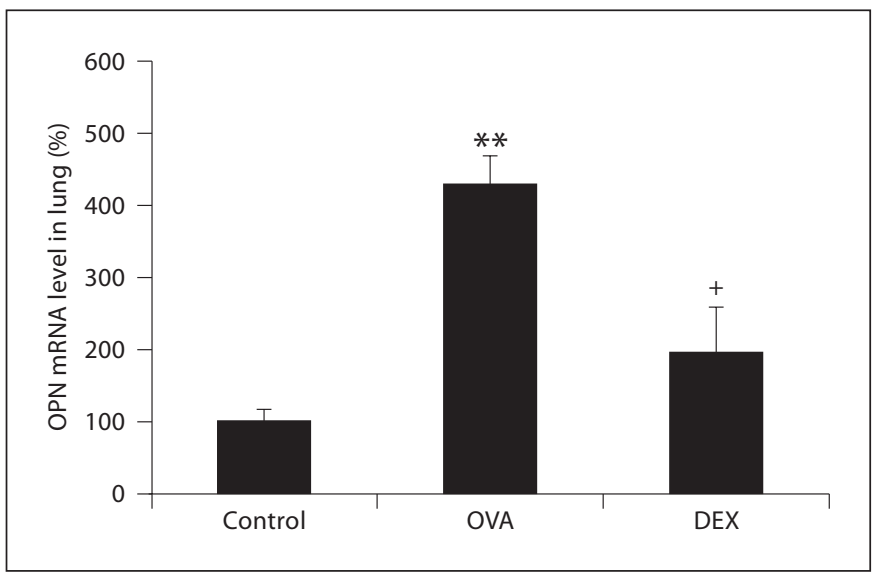

Fig. 2. OPN mRNA in the lungs and the effect of DEX on OPN mRNA. OPN mRNA expression in the lungs was significantly higher at $24 \mathrm{~h}$ after antigen challenge in the OVA-challenged mice than in the control mice. DEX significantly reduced OPN mRNA expression in the lungs. ${ }^{* *}$ OVA compared with control $(\mathrm{p}<0.01)$. ${ }^{+}$DEX compared with OVA $(\mathrm{p}<0.05)$.

Triton/BSA PBS for $2 \mathrm{~h}$ at room temperature. They were then rinsed with Tris-buffered saline ( $\mathrm{pH} \mathrm{8.6)} \mathrm{for} 15 \mathrm{~min}$. The tissues were mounted in antifade glycerol (antifade kit Fluoro-mount; Molecular Probes) and coverslipped. Similar sections were imaged for fluorescence detection (Alexa 488 and Alexa 594).

\section{Statistical Analysis}

The results are expressed as the means \pm SE. Significant differences between results were detected using Wilcoxon's test. Differences were considered significant at $\mathrm{p}<0.05$.

\section{Results}

\section{OPN Protein in BAL Fluid and the Effect of DEX on \\ OPN Protein}

The OPN protein levels in BAL fluid were significantly higher at $24 \mathrm{~h}$ after antigen challenge in the OVA-challenged mice than in the control mice. DEX significantly decreased the OPN protein levels in BAL fluid at $24 \mathrm{~h}$ after the OVA challenge (fig. 1).

\section{OPN mRNA in the Lung and the Effect of DEX on OPN $m R N A$}

OPN mRNA expression in the lung was significantly higher at $24 \mathrm{~h}$ after antigen challenge in the OVA-challenged mice than in the control mice. Furthermore, DEX significantly inhibited the expression of OPN mRNA in the lungs (fig. 2). 


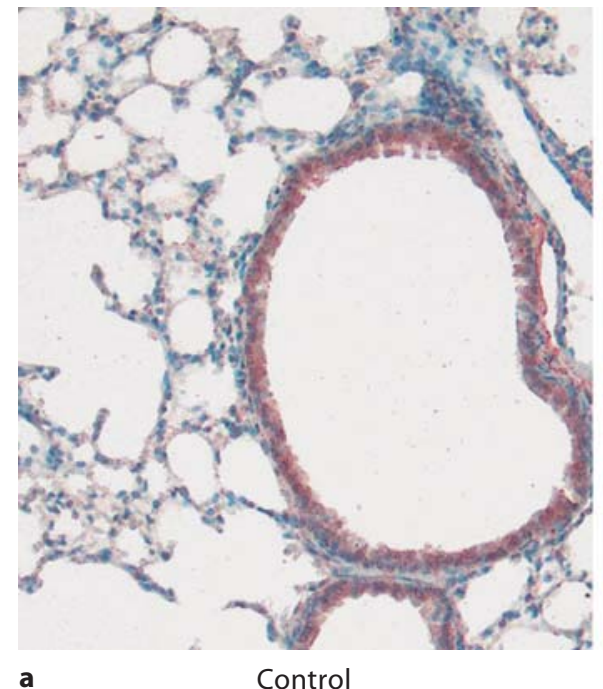

a

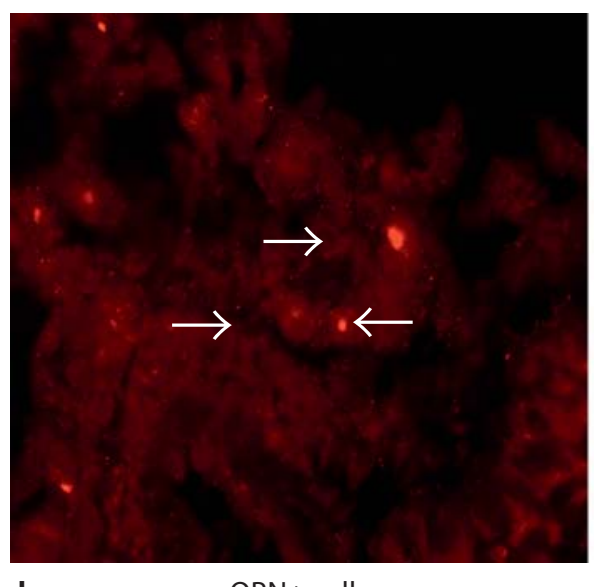

d

OPN+cell

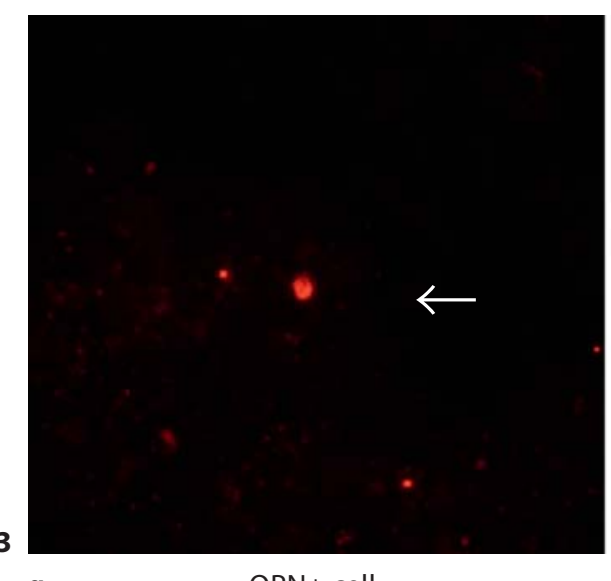

g

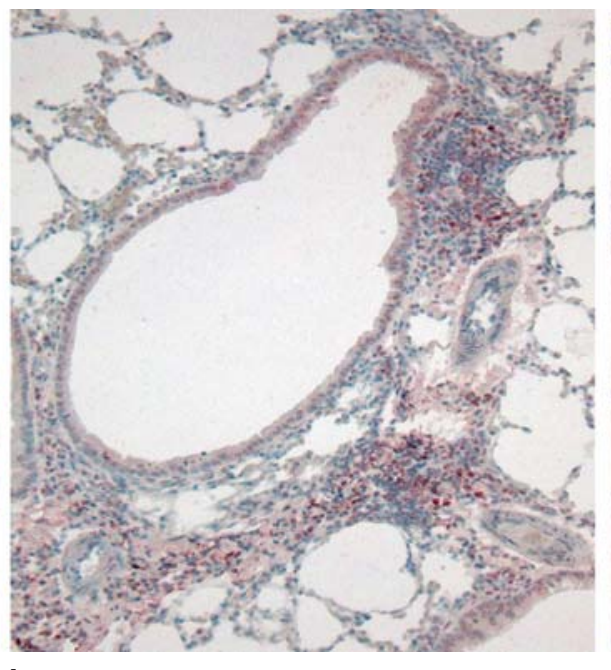

b

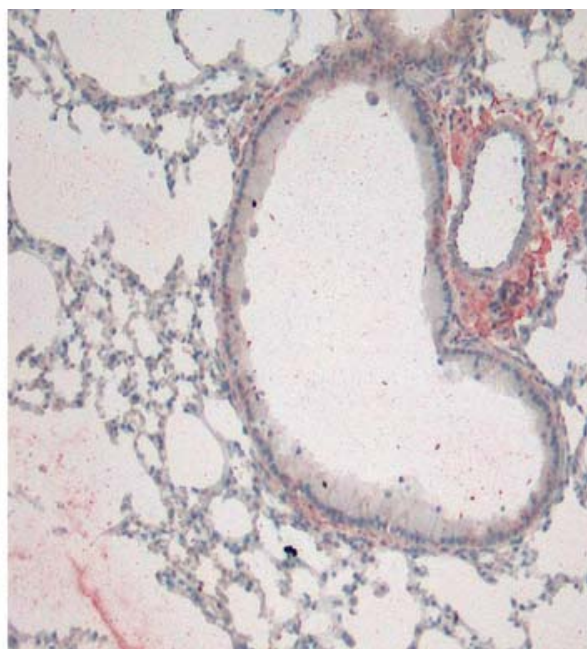

c

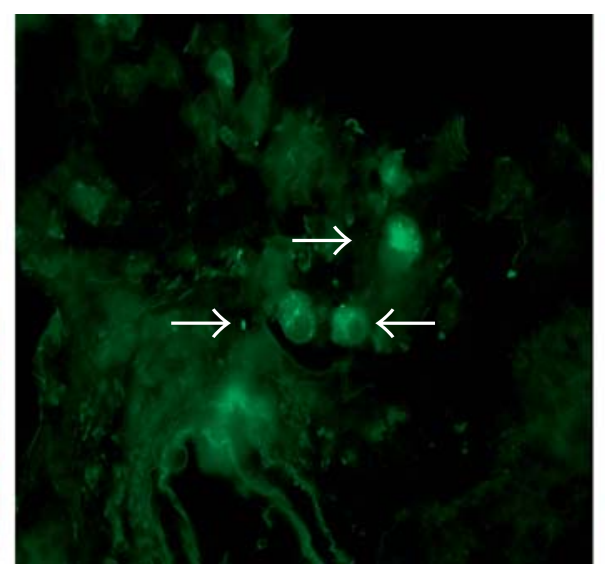

CD11c+ cell

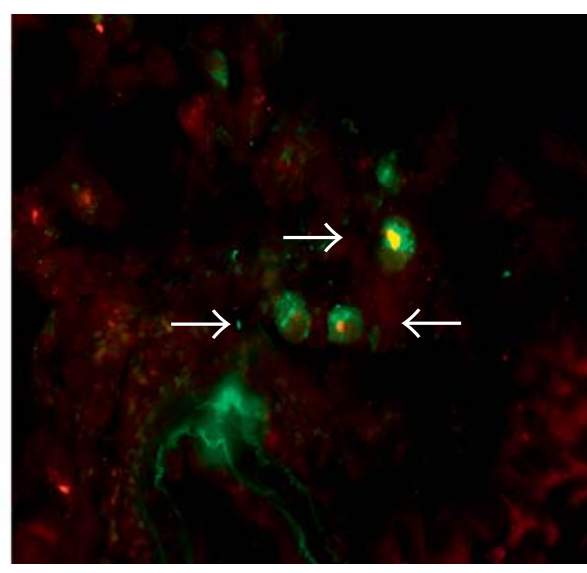

$\mathrm{OPN}+\mathrm{CD} 11 \mathrm{c}+$ cell

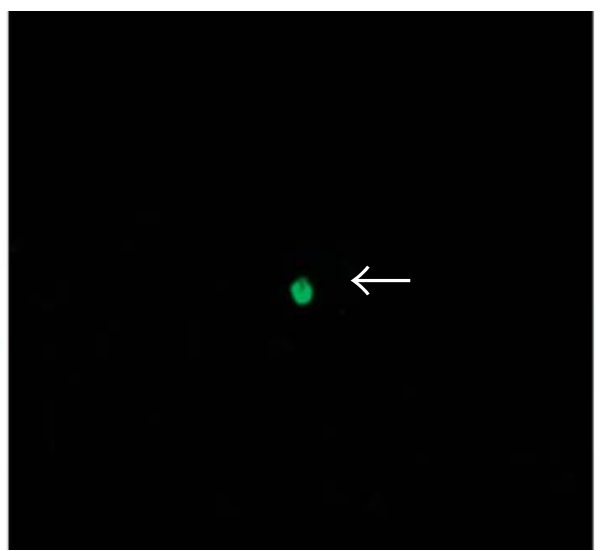

CD4+ cell

$\mathrm{OPN}+\mathrm{CD} 4+$ cell 


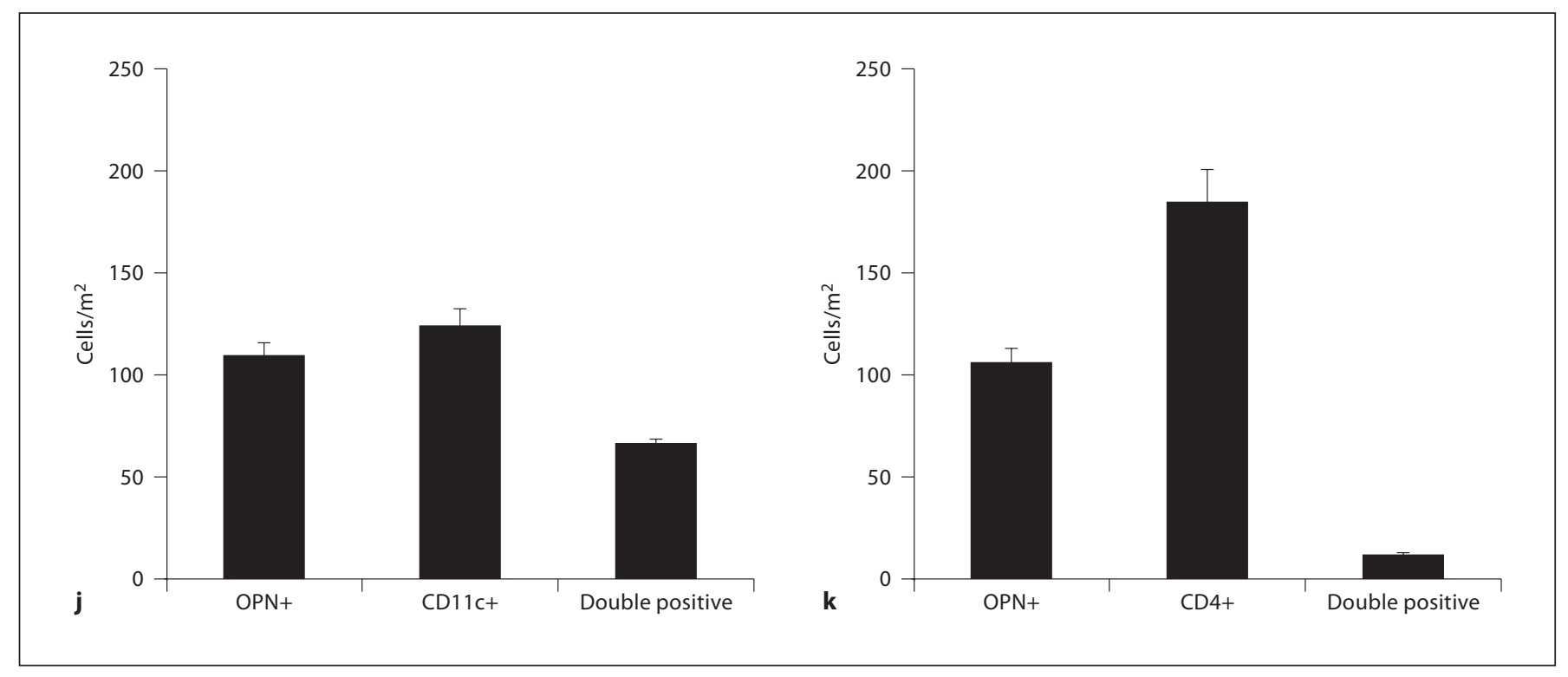

Fig. 3. Immunohistochemical staining for OPN in lung tissues and the effect of DEX on OPN expression. In the control mice, only the bronchial epithelial cells were strongly positive for OPN (a). In contrast, in the OVA-challenged mice, OPN staining was predominately observed in the infiltrating cells, and to a lesser extent, in the bronchial epithelial cells $24 \mathrm{~h}$ after OVA challenge (b). Immunohistochemical staining for OPN was significantly reduced in the DEX-treated mice (c). a Control mice; b OVA mice; c DEX mice. Most OPN-expressing cells that stained positively were mainly CD11c cells in mice (d-f, $\mathbf{j})$. In contrast, a few OPNexpressing cells belonged to the T-cell population $(\mathbf{g - i}, \mathbf{k}) \cdot \mathbf{d}$ OPN (red); e CD11c (green), and f double-positive cells (yellow). g OPN (red); h CD4 (green), and I, double-positive cells (yellow). j The numbers of CD11c-, OPN- and double-positive cells were counted. $\mathbf{k}$ The numbers of CD4-, OPN- and double-positive cells were counted.

\section{Immunohistochemical Staining for OPN and the Effect of DEX on OPN Expression}

Only the bronchial epithelial cells were strongly positive for OPN in control mice (fig. 3a). In contrast, the infiltrating cells were predominately positive for OPN, whereas bronchial epithelial cells were positive to a lesser extent in the OVA-challenged mice, as determined at $24 \mathrm{~h}$ after the OVA challenge (fig. $3 \mathrm{~b}$ ).

To identify the various types of infiltrating cells, we performed double immunofluorescence staining for OPN and CD11c, OPN and CD4.

Most OPN-expressing cells stained positively for CD11c (fig. 3d-f, j). In contrast, a few OPN-expressing cells belonged to the T-cell population (fig. $3 g-i, k$ ).

Significantly fewer cells stained positive for OPN in the DEX mice group (fig. 3c).

\section{Discussion}

In the present study, we showed that OPN expression in the lungs increases in mice with allergic asthma. In addition, we found that most OPN-expressing cells are pos- itive for CD11c, and a few are T-cells. Kohan et al. [26] reported that eosinophils also express OPN.

DCs are primary antigen-presenting cells involved in interactions with $\mathrm{T}$ cells leading to the proliferation of Th1 or Th2 cell types [27]. The findings of many studies conducted on animals and humans strongly suggest that DC function is critical to the development and regulation of the allergic state $[28,29]$.

We previously reported that significant upregulation of OPN expression is associated with successful venom immunotherapy (VIT). We evaluated OPN expression by using a gene chip microarray and clustering analyses and reported that OPN is a potential biomarker for VIT. OPN expression in monocytes and monocyte-derived DCs is significantly increased in subjects who successfully completed immunotherapy and show clinical tolerance compared to those who are hypersensitive to allergens and have not undergone immunotherapy $[30,31]$.

Previous studies have investigated the potential involvement of the Th2-associated allergic responses in airway inflammation [32] and mast cell degranulation [33]. We reported that OPN is expressed in the airways of asthmatic patients, and the level of OPN protein is positively 
correlated with the percentage of eosinophils in induced sputum collected from asthmatic patients. Anti-OPN antibodies have been shown to significantly attenuate OVAinduced eosinophilic airway inflammation in mouse models of allergic asthma [34]. Xanthou et al. [32] reported that OPN inhibited this process because they found that the administration of anti-OPN antibodies enhances allergic airway inflammation. In contrast, our results indicate that OPN plays a role in the pathogenesis of asthma by mediating migration of eosinophils into the airways [34]. Kohan et al. [26, 35] reported that OPN expression is significantly correlated with the structural changes observed in a murine model of chronic allergen-induced airway remodeling. Thus, OPN plays a role in the airway remodeling observed in asthma. In the present study, we showed that OPN performs important functions in allergic bronchial asthma.

Corticosteroids reduce airway inflammation through multiple mechanisms. First, they directly inhibit several types of inflammatory cells including the numbers of eosinophils and the quantity of cytokines, such as GM-CSF and IL-5 [36, 37]. Second, corticosteroids inhibit the activation of $\mathrm{T}$ lymphocytes and their release of cytokines (IL-4, IL-5, and IL-13) and chemokines (RANTES, eotaxins) by T lymphocytes $[36,37]$. Many inflammatory genes are expressed in asthmatic states. Corticosteroids produce their effects on responsive airway cells in asthma by activating glucocorticoid receptors to regulate the transcription of target genes. Glucocorticoid receptors may interact with the transcription factors AP-1 and nuclear factor- $\kappa \mathrm{B}$, which may be important for mediating the inflammatory effects of cytokines and chemokines in the lung [38, 39]. Corticosteroids inhibit several aspects of the inflammatory process by decreasing gene transcrip- tion and inhibit the transcription of most cytokines and chemokines that are important in the pathogenesis of asthma. Third, corticosteroids have strong inhibitory effects on DC function. They not only prevent the differentiation of monocytes into immature DCs and block maturation of DCs, but also induce apoptosis of DCs and may affect recruitment of DCs to the airway [27, 40,41].

Vascular calcification is present in many pathological conditions and is recognized as a strong predictor of future cardiovascular events. Kirton et al. [42] reported that DEX downregulated the postulated calcification-inhibitor gene OPN in pericytes. DEX treatment results in a decrease in nuclear factor- $\kappa \mathrm{B}$ protein in the nucleus.

In this study, we have demonstrated in a murine model of allergic asthma that OPN expression in the lungs is upregulated after antigen challenge. We also found that corticosteroids inhibited OPN production. We therefore conclude that the beneficial effects of corticosteroids in bronchial asthma are partly due to their direct inhibitory effects on OPN production.

\section{Acknowledgements}

We gratefully thank Allen C. Myers and Holly Rohde for helpful immunohistological staining techniques. We also thank Fumio Kokubu for helpful discussion and analysis. This work is supported, in part, by NIH grant (AI-052468).

\section{Disclosure Statement}

The authors declare that no financial or other conflict of interest exists in relation to the content of the article.

\section{References}

1 Denhart DT, Noda M, O'Regan AW, Pavlin D, Berman JS: Osteopontin as a means to cope with environmental insults: regulation of inflammation, tissue remodeling, and cell survival. J Clin Invest 2001;107:1055-1061.

2 O'Regan A: The role of osteopontin in the lung disease. Cytokine Growth Factor Rev 2003;14:479-488.

3 Zhu B, Suzuki K, Goldberg HA, Rittling SR, Denhart DT, McCulloch CA, Sodek J: Osteopontin modulates CD44-dependent chemotaxis of peritoneal macrophages through Gprotein-coupled receptors: evidence of a role for an intracellular form of osteopontin. J Cell Physiol 2004;198:155-167.
4 Yamamoto N, Sakai F, Kon S, Morimoto J, Kimura C, Yamazaki H, Okazaki I, Seki N, Fujii T, Uede T: Essential role of the cryptic epitope SLAYGLR within osteopontin in a murine model of rheumatoid arthritis. J Clin Invest 2003;112:181-188.

5 Higuchi Y, Tamura Y, Uchida T, Matsuura K, Hijiya N, Yamamoto S: The roles of soluble osteopontin using osteopontin-transgenic mice in vivo: proliferation of CD4+ T lymphocytes and the enhancement of cell-mediated immune responses. Pathobiology 2004; 71:1-11.

- 6 Koh A, da Silva AP, Bansal AK, Bansal M, Sun C, Lee H, Glogauer M, Sodek J, Zohar R:
Role of osteopontin in neutrophil function. Immunology 2007;122:466-475.

7 Diao H, Kon S, Iwabuchi K, Kimura C, Morimoto J, Ito D, Segawa T, Maeda M, Hamuro J, Nakayama T, Taniguchi M, Yagita H, Van Kaer L, Onoe K, Denhardt D, Rittling S, Uede T: Osteopontin as a mediator of NKT cell function in T cell-mediated liver diseases. Immunity 2004;21:539-550.

8 Ashkar S, Weber GF, Panoutsakopoulou V, Sanchirico ME, Jansson M, Zawaideh S, Rittling SR, Denhardt DT, Glimcher MJ, Cantor $\mathrm{H}$ : Eta (osteopontin): an early component of type-1 (cell-mediated) immunity. Science 2000;287:860-864. 
-9 Chabas D, Baranzini SE, Mitchell D, Bernard CC, Rittling SR, Denhardt DT, Sobel RA, Lock C, Karpuj M, Pedotti R, Heller R, Oksenberg JR, Steinman L: The influence of the proinflammatory cytokine, osteopontin, on autoimmune demyelinating disease. Science 2001;294:1731-1735.

-10 Ohsima S, Yamaguchi N, Nishioka K, Mima T, Ishii T, Umeshita-Sasai M, Kobayashi H, Shimizu M, Katada Y, Wakitani S, Murata N, Nomura S, Matuno H, Katayama R, Kon S, Isobe M, Uede T, Kawase I, Saeki Y: Enhanced local production of osteopontin in rheumatoid joints. J Rheumatol 2002;29: 2061-2067.

-11 Xu G, Nie H, Li N, Zheng W, Zhang D, Feng G, Ni L, Xu R, Hong J, Zhang JZ: Role of osteopontin in amplification and perpetuation of rheumatoid synovitis. J Clin Invest 2005; 115:1060-1067.

-12 Maeda K, Takahashi K, Takahashi F, Tamura N, Maeda M, Kon S, Uede T, Fukuchi Y: Distinct roles of osteopontin fragments in the development of the pulmonary involvement in sarcoidosis. Lung 2002;179:279-291.

-13 O’Regan AW, Chupp GL, Lowry JA, Goetschkes M, Mulligan N, Berman JP: Osteopontin is associated with $\mathrm{T}$ cells in sarcoid granulomas and has $\mathrm{T}$ cell adhesive and cytokine-like properties in vitro. J Immunol 1999;162:1024-1031.

14 Koguchi Y, Kawakami K, Uezu K, Fukushima K, Kon S, Maeda M, Nakamoto A, Owan I, Kuba M, Kudeken N, Azuma M, Yara S, Shinzato T, Higa F, Tateyama M, Kadota J, Mukae H, Kohno S, Uede T, Saito A: High plasma osteopontin level and its relationship with interleukin-12-mediated type $1 \mathrm{~T}$ helper cell response in tuberculosis. Am J Respir Crit Care Med 2003;167:1355-1359.

-15 Nau GJ, Guilfoile P, Chupp GL, Berman JS, Kim SJ, Kornfeld H, Young RA: A chemoattractant cytokine associated with granulomas in tuberculosis and silicosis. Proc Natl Acad Sci USA 1997;94:6414-6419.

-16 Comabella M, Pericot I, Goertsches R, Nos C, Castillo M, Blas Navarro J, Rio J, Montalban X: Plasma osteopontin levels in multiple sclerosis. J Neuroimmunol 2005;158:231239.

17 Vogt MH, Foris S, Killestein J, Knol DL, Smits M, Barkhof F, Polman CH, Nagelkerken L: Osteopontin levels and increased disease activity in relapsing-remitting multiple sclerosis patients. J Neuroimmunol 2004; 155:155-160.

18 Corrigan CJ, Kay AB: T cells and eosinophils in the pathogenesis of asthma. Immunol Today 1992;13:501-507.
9 Moller GM: Overbeek SE, Van HeldenMeeuwsen CG, Prens EP, Mulder PG, Postma DS, Hoogsteden HC: Increased numbers of dendritic cells in the bronchial mucosa of atopic asthmatic patients: downregulation by inhaled corticosteroids. Clin Exp Allergy 1996;26:517-524.

20 Robinson DS, Hamid Q, Ying S, Tsicopoulos A, Barkans J, Bentley AM, Corrigan C, Durham SR, Kay AB: Predominant Th2-like bronchoalveolar T-lymphocyte population in atopic asthma. N Engl J Med 1992;326: 298-304.

-21 Walker C, Bode E, Bore L, Hansel TT, Blaser K, Virchow JC Jr: Allergic and nonallergic asthmatics have distinct patterns of T-cell activation and cytokine production in peripheral blood and bronchoalveolar lavage. Am Rev Respir Dis 1992;146:109-115.

22 Lambrecht BN: Lung dendritic cells: targets for therapy in allergic disease. Curr Mol Med 2008;8:393-400.

23 Kurokawa M, Kokubu F, Matsukura S, Kawaguchi M, Ieki K, Suzuki S, Odaka M, Watanabe S, Takeuchi H, Akabane T, Asano K, Iwase M, Honma I, Adachi M: Effects of corticosteroid on the expression of thymus and activation-regulated chemokine in a murine model of allergic asthma. Int Arch Allergy Immunol 2005;137(suppl 1):60-68.

-24 Suzuki S, Kokubu F, Kawaguchi M, Homma T, Odaka M, Watanabe S, Matsukura S, Kurokawa M, Takeuchi H, Sasaki Y, Huang SK, Adachi M, Ota H: Expression of interleukin$17 \mathrm{~F}$ in a mouse model of allergic asthma. Int Arch Allergy Immunol 2007; 143(suppl 1):89-94.

25 Matsukura S, Kokubu F, Kubo H, Tomita T, Tokunaga H, Kadokura M, Yamamoto T, Kuroiwa Y, Ohno T, Suzaki H, Adachi M: Expression of RANTES by normal airway epithelial cells after influenza virus A infection. Am J Respir Cell Mol Biol 1998;18:255-264.

-26 Kohan M, Bader R, Puxeddu I, Levi-Schaffer F, Breuer R, Berkman N: Enhanced osteopontin expression in a murine model of allergen-induced airway remodelling. Clin Exp Allergy 2007;37:1444-1454.

27 Bharadwaj AS, Bewtra AK, Agrawal DK: Dendritic cells in allergic airway inflammation. Can J Physiol Phamacol 2007;85:686699.

28 Konno S, Eckman JA, Plunkett B, Li X, Berman JS, Schroeder J, Huang SK: Interleukin10 and Th2 cytokines differentially regulate osteopontin expression in human monocytes and dendritic cells. J Interferon Cytokine Res 2006;26:562-567.

29 Kurokawa M, Konno S, Beverly P, Susan RR, Nishimura M, Adachi M, Huang SK: Regulatory role of dendritic cell-derived osteopontin in systemic allergen sensitization (submitted).
30 Konno S, Golden DBK, Schroeder J, Hamilton RG, Lichtenstein LM, Huang SK: Increased expression of osteopontin is associated with long-term bee venom immunotherapy. J Allergy Clin Immunol 2005;115: 1063-1067.

-31 Konno S, Golden DBK, Schroeder J, Hamilton RG, Lichtenstein LM, Huang SK: Level of osteopontin is increased after bee venom immunotherapy. J Allergy Clin Immunol 2005; 115:1317.

32 Xanthou G, Alissafi T, Semitekolou M, Simoes DC, Economidou E, Gaga M, Lambrecht BN, Lloyd CM, Panoutsakopoulou V: Osteopontin has a crucial role in allergic airway disease through regulation of dendritic cell subsets. Nat Med 2007;13:570-578.

- 33 Nagasaka A, Matsue H, Matsushima H, Aoki R, Nakamura Y, Kambe N, Kon S, Uede T, Shimada S: Osteopontin is produced by mast cells and affects IgE-mediated degranulation and migration of mast cells. Eur J Immunol 2008;38:489-499.

34 Takahashi A, Konno S, Kurokawa M, Hizawa N, Ito K, Kon S, Ashino S, Isada A, Hattori T, Maeda Y, Nishimura T, Uede T, Huang SK, Nishimura M. Osteopontin: a novel chemoattractant of eosinophils in asthma. Clin Exp Allergy 2009 (in press).

35 Kohan M, Breuer R, Berkman N: Osteopontin induces airway remodeling and lung fibroblast activation in a murine model of asthma. Am J Respir Cell Mol Biol 2009 (in press).

36 Barnes PJ: Mechanism of action of glucocorticoids in asthma. Am J Respir Crit Care Med 1996;154:S21-S26.

37 Belvisi MG: Regulation of inflammatory cell function by corticosteroids. Proc Am Thorac Soc 2004;1:207-214.

38 Ray A, Prefontaine KE: Physical association and functional antagonist between the p65 subunit of transcription factor NF- $\kappa \mathrm{B}$ and the glucocorticoid receptor. Proc Natl Acad Sci USA 1994;91:752-756.

39 Barns PJ: Corticosteroid effects on cell signaling. Eur Respir J 2006;27:413-426.

-40 Piemonti L, Monti P, Allavena P, Sironi M, Soldini L, Leone BE, Socci C, Adorini L: Glucocorticoids affect human dendritic cell differentiation and maturation. J Immunol 2000;164:4443-4451.

41 Brokaw JJ, White GW, Baluk P, Anderson GP, Umemoto EY, McDonald DM: Glucocorticoid-induced apoptosis of dendritic cells in the rat tracheal mucosa. Am J Respir Cell Mol Biol 1998;19:598-605.

42 Kirton JP, Wilkinson, Canfield AE, Alexander MY: Dexamethasone downregulates calcification-inhibitor molecules and accelerates osteogenic differentiation of vascular pericytes: implications for vascular calcification. Circ Res 2006;98:1264-1272. 